\title{
Assessing Mercury Pollution Using Black Stork Eggshells
}

\author{
Anda Abola \\ Institute of Atomic Physics and Spectroscopy \\ University of Latvia \\ Riga, Latvia \\ anda.abola@lu.lv \\ Rita Veilande \\ Institute of Atomic Physics and Spectroscopy \\ University of Latvia \\ Riga, Latvia \\ rita.veilande@lu.lv
}

\author{
Maris Strazds \\ Institute of Biology \\ University of Latvia \\ Riga, Latvia \\ mstrazds@latnet.lv \\ Zanda Gavare \\ Depasrtment of Physics \\ Latvia University of Life Sciences and Technology \\ Jelgava, Latvia \\ zanda.gavare@gmail.com
}

Female birds whose bodies contain environmental contaminants produce eggs with shells that are likewise contaminated, making bird eggshells appropriate indicators for monitoring environmental toxins. Common contaminants include organic mercury compounds, especially methylmercury, which are known to bioaccumulate and biomagnify in the food chain. Black storks (Ciconia nigra) predominantly consume fish and are thus at risk for high mercury intake. In this study, we used eggshells of black storks as a proxy to reconstruct the concentration levels and distribution of mercury, a wellknown toxic element, in various parts of Latvia. Preliminary analyses have shown that deposition levels of mercury vary in different parts of the eggshell. Specifically, the shell and shell membrane differ in their level of mercury contamination by an average factor of nine; therefore, we measured the mercury content in these components separately whenever possible. We analysed 34 eggshell samples from nesting sites in Latvia using an atomic absorption spectrometer with Zeeman correction Lumex RA-915M and its attachment for pyrolytic combustion. We found that mercury concentrations varied from 5 to $22 \mathrm{ng} / \mathrm{g}$ in eggshells and from 42 to $293 \mathrm{ng} / \mathrm{g}$ in shell membranes. We discuss possible contamination sources and reasons behind this disparity.

Keywords - black stork, eggshells, mercury

\section{INTRODUCTION}

Mercury is one of the most toxic elements affecting living organisms and the environment. All of its compounds are deemed toxic, and its organic compounds are generally more toxic than its inorganic compounds. Mercury's methylation processes occurs in aquatic environments [1] [3], resulting in methylmercury, which is highly toxic. Afterwards, methylmercury enters the food chain through small organisms, such as algae and plankton, and it bioaccumulates and biomagnifies, rapidly increasing its concentration [4].

Because of these biogeochemical processes, even moderate mercury concentration levels in the surrounding environment can result in serious toxicity for organisms that are positioned higher on the food chain, such as large fish, fish-eating birds, and humans [3], [5]. Birds' intestines absorb only a small percentage of inorganic mercury but almost all organic mercury, and nearly all mercury in fish is methylmercury [6].

Bird eggs have become a widely used tool for mercury pollution assessment because utilizing them is noninvasive, and they are relatively easy to collect [7]. Numerous studies have analysed mercury content in various egg parts, including the yolk, albumen, membrane, and shell of many bird species (e.g. [7] -[10]), and have found that the egg content has considerably higher mercury concentrations than the egg shells [7], [9]. Several studies have established correlation between mercury concentrations in different egg components [7], [10], as well as in eggs and blood samples [8]. While these findings cannot be extrapolated to other bird species, as correlations vary and there is some concern about differences between methodologies when processing eggshells [10], identifying 
correlations in this area could widen possibilities and options when working with endangered species.

Measuring mercury from eggshells offers a number of benefits in comparison with direct measurements of mercury content in streams, fish ponds and prey items of storks. Eggshells retain contaminants that are deposited within them, and thus can be used to trace the contaminant's origin. Additionally, eggshells are useful because they do not require specific storage conditions, can be easily archived for long periods of time [11], and can be collected using non-invasive methods. Moreover, using shells of hatched or failed eggs ensures that no viable eggs are lost.

The black stork (Ciconia nigra) is predominantly a fisheating bird and forages primarily in streams, fish ponds, and similar aquatic environments. They usually lay eggs with an interval of two days [12]. The time frame between the arrival of females on the breeding grounds in Latvia and the laying of their first eggs varies from four to fourteen days (mean = 7) [13]. Consequently, the contaminants that are transferred from the mother to her eggs likely represent the contaminants that are present around the nesting site at the time of egg laying.

Black storks often remove any eggshells that remain in the nest after hatching. Less commonly, halved or smashed egg remains can be found under nests that were depredated by predators. In both cases, researchers can obtain eggshells without approaching (i.e. climbing to) the nest itself, thereby limiting disturbance, which is especially critical for endangered species such as the black stork [14]. A study by Černova revealed unexpectedly high mercury concentration levels in the blood and livers of juvenile black storks [15], providing a basis for our study. We aimed to further investigate contaminants in black storks by testing different parts of their eggshells for mercury. We analysed various types of egg remains from black storks in different parts of Latvia for mercury to determine whether these eggs can be used to understand mercury pollution levels and reconstruct contamination history in the area.

\section{MATERIAL AND METHODS}

\section{A. Eggshells}

We used black stork eggshells collected from 20072009 and 2018 for this study. We analysed a total of 34 samples from $>30$ nesting sites in Latvia. The eggshells that we collected varied in size, ranging from almost whole eggs to fragments on the ground under the nest. We placed eggshells in three categories: (1) halves and "caps" remaining after hatching, which adult birds often (but not always) threw out of the nest, (2) remnants of eggs depredated by predators at different stages of incubation, and (3) remnants of complete eggs, resulting from conflicts between storks, that were thrown out of the nest.

When stork conflicts occur, they are typically during the initial period of incubation [13]. Consequently, eggs thrown out of nests as a result of such conflicts are mostly fresh or only partially incubated, and the membrane adheres very tightly to the shell and is difficult to separate. In the case of hatched eggs, remaining membrane fragments usually separate on their own. This likely results from processes during incubation in which the egg shell becomes thinner and more fragile as the growing chick uses calcium from the shell to form its skeleton [16]. Damage from predators can occur at any stage of the incubation period. Camera traps documented predation on days 9 and 27 after the first egg was laid (by pine martens) and on days 10, 14 and 18 (by white-tailed sea eagles). Incubating one egg takes an average of 32 days [13].

\section{B. Eggshell collection and preparation}

We collected eggshells in almost all regions of Latvia (Fig. 1). We immediately labelled all eggshell samples with a nest number and described the shell characteristics. We also tried to determine the hatching status for each eggshell (hatched, unhatched or unknown; Table 1). Afterwards, we air-dried eggshells and cleaned larger pieces with a soft brush as thoroughly as possible to remove any debris.

TABLE 1 NUMBER OF EGGSHELLS BY HATCHING STATUS

\begin{tabular}{|c|c|c|c|}
\hline Hatched & Possibly hatched & Unhatched & Unknown \\
\hline 3 & 9 & 8 & 14 \\
\hline
\end{tabular}

Prior to taking measurements, we separated the inner membrane from the eggshell when possible. Otherwise, we used samples mixed with both inner membrane and eggshell. To homogenize the samples, we crushed the shells using a mortar and pestle.

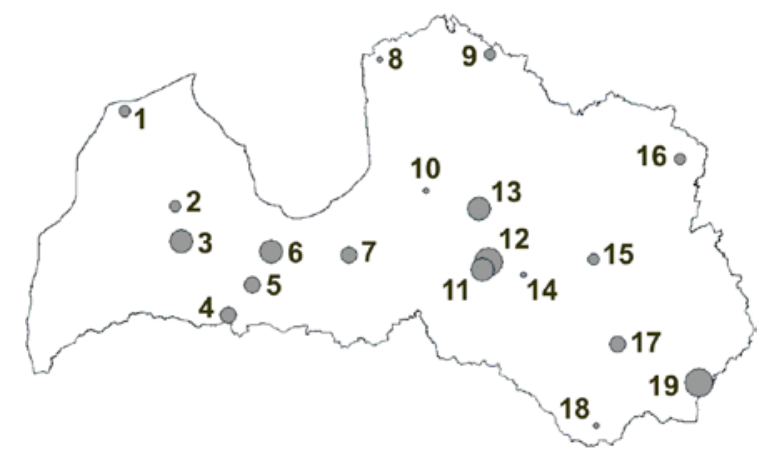

Fig. 1 Distribution of analyzed samples (only mixed samples shown) in the territory of Latvia. Size of the points is depicted in five classes according to natural breaks (jenks) of data: 1) 8-14, 2) 14-20, 3) 20-29, 4) 29-39, 5) 39-60. If a nest had more than one sample (i.e. \# 18), we displayed the largest value. See Table 2 for sample numbers.

\section{Mercury measurements}

We performed total mercury concentration measurements using an atomic absorption spectrometer with Zeeman correction LUMEX RA-915M and its attachment for pyrolytic analysis PYRO-915+. The threshold of detection was approximately $2 \mathrm{ng} / \mathrm{g}$ for our chosen setup and sample type [17].

To conduct measurements, we first weighed the sample, followed by thermal decomposition occurring inside atomizer PYRO-915+. Subsequently, we measured the absorption of the mercury $254 \mathrm{~nm}$ resonance radiation and calculated its concentration. Pyrolytic combustion allows 
Environment. Technology. Resources. Rezekne, Latvia Proceedings of the $13^{\text {th }}$ International Scientific and Practical Conference. Volume 1, 12-16

direct measurements without specific pretreatment procedures, diminishing possible sample contamination and providing almost instant results.

We calibrated the spectrometer and periodically tested it using a certified reference material of mussel tissue ERM-278k (by the European Commision Joint Research Centre). We used chicken eggshells, which we previously confirmed to be sufficiently mercury free (rendering mercury concentration below threshold of detection, close to $0 \mathrm{ng} / \mathrm{g}$ ), as blank samples, as well as to test the equipment's cleanliness. The average measured sample size was 50-100 mg dry weight (d.w.) for eggshells and mixed samples and 20-30mg d.w. for inner membranes. We repeated measurements for each sample 5 times on average and calculated the standard deviation.

\section{RESULTS AND DISCUSSION}

\section{A. Results}

We separated all measurements into three groups eggshells, membranes, and mixed samples; the latter group was the largest. Since we only collected hatched or failed eggs, and often crushed eggshell parts, the quality of the available samples differed. All of our samples were at or higher than the mercury detection limit (Table 2, sample name indicates the nest number and year when the collected egg was laid).

As expected, eggshells had the lowest mercury concentrations, ranging from 6 to $22 \mathrm{ng} / \mathrm{g}$. Inner membranes contained more mercury, with the lowest concentration we recorded at $42 \mathrm{ng} / \mathrm{g}$, but results varied among nesting sites. Typically, concentrations were over $100 \mathrm{ng} / \mathrm{g}$, ranging up to $300 \mathrm{ng} / \mathrm{g}$.

In cases where both eggshells and membranes were available for analyses, membranes contained much more mercury than the eggshell itself (Fig 2). Samples had an average ratio of mercury in the membrane to mercury in the eggshell of 9:1, with results ranging from ratios of $5: 1$ to 13:1.

\section{B. Discussion}

All of our samples contained a detectable amount of mercury, but there was a large degree of variation in the amount of mercury in each sample. We were unable to determine the hatching status (i.e. hatched or not hatched) of our samples with certainty (Table 1), making our results more difficult to interpret. We could only determine the origin of eggshells if there was a camera trap at the nest documenting the hatching process. Strazds and Kuze began using camera traps at black stork nests in 2011 and initially only a tracked a few nests per year [18] Even if juveniles are present in a nest and it appears to be successful, shells on the ground do not necessarily mean that an egg has hatched because a stork conflict may have occurred in spring, resulting in the first clutch being thrown out of the nest and shell pieces remaining on the ground [13]. An additional problem may be that carnivores can destroy the eggs at different stages of incubation. It is unknown whether the membrane separates easily only from hatched eggs, or if this also occurs when an embryo is eaten during the late stage of development (i.e. shortly before hatching), and if so, how long before hatching.

TABLE 2 MERCURY CONCENTRATIONS IN EGGSHELL SAMPLES.

\begin{tabular}{|c|c|c|c|c|c|}
\hline \multirow[t]{2}{*}{ Year } & \multirow{2}{*}{$\begin{array}{c}\text { Sample } \\
\text { name }\end{array}$} & \multicolumn{3}{|c|}{ Concentration, ng/g } & \multirow{2}{*}{$\begin{array}{l}\mathrm{N}^{0} \text { in } \\
\text { map }\end{array}$} \\
\hline & & Eggshells & Membranes & Mixed & \\
\hline \multirow[t]{5}{*}{2007} & 064502-07 & & $160 \pm 10$ & $16 \pm 1$ & 9 \\
\hline & 173401-07 & & 221 & $20 \pm 3$ & 2 \\
\hline & 623303-07 & & & $35 \pm 4$ & 13 \\
\hline & 672503-07 & $8 \pm 1$ & $85 \pm 7$ & $12 \pm 1$ & 14 \\
\hline & $752622-07$ & & 138 & $16 \pm 3$ & 15 \\
\hline \multirow[t]{6}{*}{2008} & 104501-08 & & & $15 \pm 2$ & 1 \\
\hline & 272401-08 & & $211 \pm 8$ & $25 \pm 4$ & 5 \\
\hline & 532304-08 & $11 \pm 1$ & $101 \pm 13$ & & \\
\hline & 553630-08 & & & $12 \pm 6$ & 10 \\
\hline & \begin{tabular}{|l|}
$622701-08$ \\
\end{tabular} & & & $60 \pm 12$ & 12 \\
\hline & 781601-08 & & & $29 \pm 1$ & 17 \\
\hline \multirow[t]{8}{*}{2009} & 182901-09 & & $236 \pm 4$ & $33 \pm 4$ & 3 \\
\hline & 183501-09 & $12 \pm 1$ & $58 \pm 12$ & & \\
\hline & \begin{tabular}{|l|} 
292952-09 \\
\end{tabular} & $22 \pm 1$ & $293 \pm 30$ & $37 \pm 8$ & 6 \\
\hline & 553630-09 & $9 \pm 1$ & $56 \pm 17$ & & \\
\hline & 622606-09 & & & $39 \pm 2$ & 11 \\
\hline & 631702-09 & $22 \pm 4$ & $200 \pm 30$ & & \\
\hline & 750601-09 & & & $14 \pm 4$ & 18 \\
\hline & \begin{tabular}{|l|}
$873802-08$ \\
\end{tabular} & & & $19 \pm 4$ & 16 \\
\hline \multirow[t]{15}{*}{2018} & 103704-18 & & $143 \pm 56$ & & \\
\hline & $173402-17$ & $17 \pm 1$ & & & \\
\hline & $182902-18$ & & $107 \pm 39$ & & \\
\hline & 242002-18 & & & $28 \pm 2$ & 4 \\
\hline & 262201-18 & $9 \pm 1$ & $79 \pm 11$ & & \\
\hline & 452801-18 & & & $27 \pm 7$ & 7 \\
\hline & 492801-18 & $12 \pm 2$ & $128 \pm 36$ & & \\
\hline & 505203-18 & & & $11 \pm 4$ & 8 \\
\hline & 562104-17 & $7 \pm 2$ & & & \\
\hline & 644185-18 & & $123 \pm 13$ & & \\
\hline & 750601-18.1 & & & $10 \pm 2$ & 18 \\
\hline & \begin{tabular}{|l|}
$750601-18.2$ \\
\end{tabular} & & & $12 \pm 3$ & 18 \\
\hline & 804402-18 & $7 \pm 1$ & & & \\
\hline & 831703-17 & & $90 \pm 24$ & & \\
\hline & \begin{tabular}{|l|}
$881102-18$ \\
\end{tabular} & $6 \pm 2$ & & $51 \pm 11$ & 19 \\
\hline
\end{tabular}

It is also unknown which processes affect the separation of the membrane in non-productive (addled) eggs. Strazds et al. determined the amount of DDT in eggs [19] and found that in some, eggs membranes detached very easily in some but were inseparable in others. Camera trap and webcam data show that adult birds may accidentally squash addled eggs that have remained in the nest and discard them afterwards [13]. As a result, remains of unhatched eggshells may be present under successful nests. Thus, undocumented findings from previous years must be treated with caution, regardless of how they were labelled at the time of collection. Further analysis of the amount of mercury in egg membranes that may have been deposited from the embryo 
during egg development should only be performed on eggshells/ membranes whose status is known with certainty.

Mixed samples contain an unspecified amount of eggshell and membrane stuck together, so their respective contributions to the final concentration cannot be determined. Thus, mixed samples give less precise results and are difficult to use. This explains why mercury values in mixed samples are lower than those of membranes and higher than for eggshells. Nevertheless, mixed samples give some indication of pollution levels if no other data are available.

There are several possible explanations for the difference in mercury concentrations between eggshells and membranes. First, the difference could be purely chemical. Membranes are organic in nature, consisting mostly of elastin-like protein surrounded by muccopolysaccaride mantle. Conversely, eggshells are predominantly inorganic, and their organic compound, a polysaccharide complex with calcium binding properties, is distributed across the shell unevenly [19]. Thus, the organic matrix may be more prone to bonding mercury compounds. Alternatively, the difference in concentrations could result from the physiology of egg formation. Bird eggs swell in utero of the female prior to the process of eggshell mineralization [19]. The location of "initial mercury" in the female body may also play some role if contaminants are deposited in the organs where organic egg content is formatted, but not the eggshells.

Among samples analysed thus far, nests in some regions of Latvia are under-represented (Zemgale, Sēlija) or are not represented at all (south-west Kurzeme; Fig. 1), though samples have been collected from nests there. Therefore, we cannot yet adequately draw conclusions about the prevalence of mercury pollution in the country. However, our results indicate some, although not very high, presence of mercury in the surrounding environment.

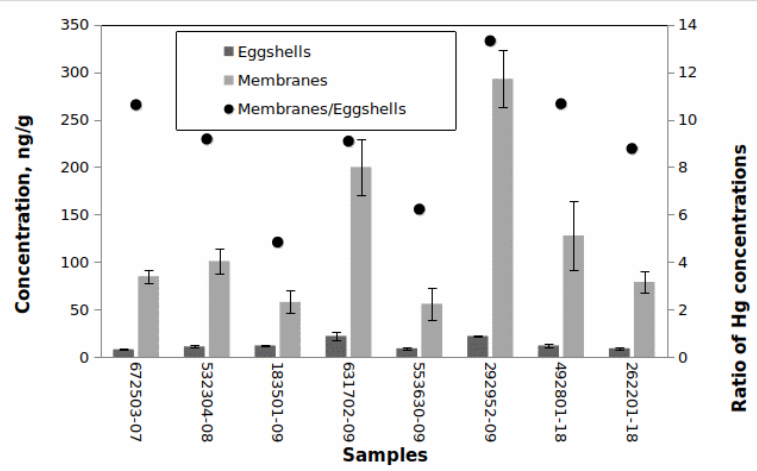

Fig. 2 Comparison of mercury concentration in eggshells (darker bars to the left) and membranes (lighter bars to the right) in 8 samples for which we successfully separated membranes from eggshells. The secondary Y-axis shows the mercury concentration ratio of membranes to eggshells (dark bullets)
Possible local sources of mercury include anthropogenic activity such as peat extraction [21], forestry [22], cement production [23], illegal dumps and waste incineration (van Veizen et al., 2002 [24], Bogans [25], and historical presence of military forces from World War I and II [26]. Possible natural sources of mercury include beaver ponds [26]. There are several peat bogs near the nests with the highest mercury concentrations, and an ex-military base is situated near No. 5 (see Fig.1). These potential mercury sources could influence the varying mercury concentration levels that we exhibited in different nests. Peterson et al. found that eggshells of older embryos had less mercury, which they speculated was influenced by changes in the shell matrix during embryo growth [10]. This is a possible factor explaining our results for addled eggs. Another possible source of contamination is connected with female choice of wintering locations and/or staging grounds on the way back to the breeding grounds. In this case, mercury might be "imported" from another country. While existing data does not allow us estimate of mercury contamination trends over time, we plan to continue our ongoing study to expand our dataset, which is now incomplete for most years.

\section{CONCLUSIONS}

Our preliminary results reveal that concentrations in various eggshell parts, specifically the eggshell and inner membrane, differ by a ratio of 1:9. Interpreting our results is difficult because of many unknowns, such as whether or not eggs were hatched and what factors affect membrane separability from eggshells. Eggshells are a potential material to use for mercury contamination assessments, but more data are required to study how spatial and temporal components influence mercury accumulation in eggshells.

\section{ACKNOWLEDGEMENTS}

This work was supported by the Latvian Council of Science No. lzp-2020/1-0005. We collected all eggshells with respective permits issued by the Nature Conservation Board of Latvia (Dabas Aizsardzības pārvalde). The camera traps used to obtain black stork phenology and other data mentioned in this paper, from 2016 to the present, were provided through the University of Latvia's project "Development of the science infrastructure of the national research center for forest and water resources."

\section{REFERENCES}

[1] F. M. M. Morel, A. M. L. Kraepiel and M. Amyot, "The chemical cycle and bioaccumulation of mercury," Annual Review of Ecology and

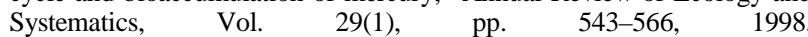
https://doi.org/10.1146/annurev.ecolsys.29.1.543

[2] S. R. Segade, T. Dias and E. Ramalhosa, "Mercury methylation versus demethylation: main processes involved," in Methylmercury: Formation, Sources and Health Effects, A.P. Clampet, Ed. New York: Nova Science Publishers, 2011, pp. 123-166.

[3] D. Evers, "The Effects of Methylmercury on Wildlife: A Comprehensive Review and Approach for Interpretation" in The Encyclopedia of the Anthropocene, D. A. DellaSala and M. I. Goldstein, Eds. Oxford: Elsevier, 2018, vol. 5, pp. 181-194.

[4] G. Harding, J. Dalziel and P. Vass, "Bioaccumulation of methylmercury within the marine food web of the outer Bay of Fundy, Gulf 
of Maine”, PLOS ONE, Vol.13(7), 2018. https://doi.org/10.1371/journal.pone.0197220

[5] C. A. Eagles-Smith , J. T. Ackerman, S. E.W. De La Cruz and J. Y. Takekawa, "Mercury bioaccumulation and risk to three waterbird foraging guilds is influenced by foraging ecology and breeding stage," Environmental Pollution, Vol. 157, pp. 1993-2002, 2009. https://doi.org/10.1016/j.envpol.2009.03.030

[6] C. J. Henny and J. E. Elliott, “Toxicology” in Raptor Research and Management Techniques Manual, Second Edition, D.M. Bird, K.L. Bildstein, Eds. British Columbia, Canada: Hancock House Publishing, Ltd. Surrey, 2007 pp. 329-350.

[7] R. L. Brasso, S. Abel and M. J. Polito "Pattern of mercury allocation into egg components is independent of dietary exposure in gentoo penguins", Archives of Environmental Contamination and Toxicology, Vol.62, pp.494-501, 2012. https://doi.org/10.1007/s00244011-9714-7

[8] D. C. Evers, K.M. Taylor, A. Major, R.J. Taylor, R.H. Poppenga and A.M. Scheuhammer, "Common Loon Eggs as Indicators of Methylmercury Availability in North America,” Ecotoxicology Vol. 12, pp. 69-81, 2003. https://doi.org/10.1023/A:1022593030009

[9] A. Aliakbari, M. Savabieasfahani and S.M. Ghasempouri, "Mercury in Egg and Eggshell of Whiskered Tern (Chlidonias hybrida) from Anzali Wetlands of the Caspian Sea, Iran,” Bulletin of Environmental Contamination and Toxicology, Vol. 86, pp. 175-179, 2011. https://doi.org/10.1007/s00128-010-0155-1

[10] S. H. Peterson, J. T. Ackerman, C. A. Eagles-Smith, C. A. Hartman and M.P. Herzog, "A critical evaluation of the utility of eggshells for estimating mercury concentration in avian eggs," Environmental Toxicology and Chemistry, Vol.36, Issue 9, pp. 2417--2427, 2017. https://doi.org/10.1002/etc.3777

[11] L.-Q. Xu, X.-D. Liu, L.-G. Sun, Q.-Q. Chen, H. Yan, Y. Liu, Y. H. Luo, J. Huang, "A 700-year record of mercury in avian eggshells of Guangjin Island, South China Sea,” Environmental Pollution, Vol. 159, Issue 4, pp. 889-896, 2011. https://doi.org/10.1016/j.envpol.2010.12.021

[12] G. Janssen, M. Hormann and C. Rohde, Der Schwarzstorch (Ciconia nigra), Die Neue Brehm-Bücherei Bd. 468, Hohenwarsleben, Deutschland : Westarp Wissenschaften, 2004.

[13] M. Strazds, unpublished data

[14] V. Kerus, A. Dekants, A. Auniṇš un I. Mārdega, Latvijas ligzdojošo putnu atlanti 1980-2017, Putnu skaits, izplatība un to pārmaiņas. Rīga: Latvijas Ornitologijas biedrība, 2021.

[15] J. Černova, "Ekoloǵiskā piesārnojuma kumulācija melnā stārḳa (Ciconia nigra) organismā," Internatūras prakses atskaites darbs. Latvijas Lauksaimniecības Universitāte. Jelgava, 2015.

[16] S. E. Solomon, Egg and Eggshell Quality. London: Manson Publishing Ltd, 1997
[17] Lumex Instruments, Product catalog, Versatile Zeeman mercury analyzer RA-915M with pyrolyzer PYRO-915+ [Online.] Available: https://www.lumexinstruments.com/catalog/atomic-absorptionspectrometry/ra-915m-pyro-915.php [Accessed March 21, 2021

[18] M. Strazds and J. Kuze, "Use of trail-cameras in studies of Black Stork behavior and ecology: gains, limitations and the first essential results”, Actes du Colloque Cicogne noire. Ornithos Hors-serie, $n^{\circ}$ 1/2016, pp. 12-13, 2016.

[19] M. Strazds, H. G. Bauer, Ü. Väli, A. Kukāre and V. Bartkevičs, "Recent impact of DDT contamination on Black stork eggs," Journal of Ornithology, Vol. 156, pp. 187-198, 2015. https://doi.org/10.1007/s10336-015-1244-Z

[20] R. G. Board and R. Fuller (Eds.) Microbiology of the avian egg. London, UK: Chapman \& Hall, 1994

[21] S. Osterwalder, K. Bishop, C. Alewell, J. Fritsche, H. Laudon, S. Åkerblom and M. B. Nilsson, "Mercury evasion from a boreal peatland shortens the timeline for recovery from legacy pollution," Scientific Reports, Vol. 7, Article number: 16022, 2017. https://doi.org/10.1038/s41598-017-16141-7

[22] P. Porvari, M. Verta, J. Munthe and M. Haapanen, "Forestry practices increase mercury and methyl mercury output from boreal forest catchments," Environment Science and Technology, Vol. 37(11), pp. 2389-2393, 2003. https://doi.org/10.1021/es0340174

[23] M. L. Jones, D. L. Laudal and J. H. Pavlish, "Mercury Emission Monitoring for the Cement Industry," IEEE Cement Industry Technical Conference Record, Miami, FL, USA, pp. 161-170, 2008. https://doi.org/10.1109/CITCON.2008.20

[24] D. van Veizen, H. Langenkamp, G. Herb, "Review: mercury in waste incineration”, Waste Management and Research, Vol. 20, pp. 556568, 2002. https://doi.org/10.1177/0734242X0202000610

[25] E. Bogans, J. Skudra, A. Svagere and Z. Gavare, “Analysis of Mercury Pollution in Air in Urban Area of Riga Using Atomic Absorption Spectrometry", In: Sustainable Development, Knowledge Society and Smart Future Manufacturing Technologies, World Sustainability Series, pp 219-228, 2015. https://doi.org/10.1007/978-3-319-14883-0_15

[26] K. Gębka, J. Bełdowski and M. Bełdowska, "The impact of military activities on the concentration of mercury in soils of military training grounds and marine sediments," Environment Science and Pollution Research, Vol. 23, pp. 23103-23113, 2016. https://doi.org/10.1007/s11356-016-7436-0

[27] V. Roy, M. Amyot, R. Carignan, "Beaver Ponds Increase Methylmercury Concentrations in Canadian Shield Streams along Vegetation and Pond-Age Gradients", Environmental Science and Technology, Vol. 43 (15), pp. 5605-5611, 2009. https://doi.org/10.1021/es901193x 